\title{
The Contribution of Educational Robotics and Constructivist Approach to Computational Thinking in the 21st Century
}

\author{
Istikomah $^{1}$, Cucuk W Budiyanto ${ }^{2}$ \\ \{istikomah13026@student.uns.ac.id ${ }^{1}$, cbudiyanto@staff.uns.ac.id $\left.{ }^{2}\right\}$ \\ Sebelas Maret University, Jl. Ir Sutami No 36A, Surakarta, Indonesia ${ }^{12}$
}

\begin{abstract}
Recent years later, there have been researches exploring the importance of computational thinking as an important skill needed by the students to manage activities in all disciplines. The development of computational thinking requires media or tool to help the students develop skill through their experience. Robotics can be used as a media to give students opportunities with the learning by their experience. The correct approach is needed to help the students develop computational thinking through their experience with robotics. A constructivist approach is a prominent approach to teaching with the learning experience. The constructivist approach may potentially be considered of the development of computational thinking skills. This paper reviews the contribution of robotics and constructivist approach to computational thinking. The insight from the reviewed papers, subsequently, was analysed the effect of the use of the robotics and constructivist approach to computational thinking.
\end{abstract}

Keywords: educational robotics, computational thinking, constructivist approach.

\section{Introduction}

Since the industrial revolution era in the late $20^{\text {th }}$-century, the technology and computer science has become the main focus on around the world [1]. The technology leads the all activities development countries, the significance of a good academic must be considered as a high aspect of the educational system [2]. Therefore the educational system must be prepared their students with good skills including computational thinking skill. Recently, there has been growing recognition of the importance of computational thinking in controlling and managing cognitive activities, as well as understanding and solving problems in a wide range of contexts, not only in the field of computer science but in all disciplines [2].

Computational Thinking (CT) has been described as an essential skill which everyone should learn and can include in skill set [3]. Computational thinking is an important skill for everyone and it should be considered as an important component of students' analytical ability along with reading, writing, and arithmetic [4]. CT conceptualizing not programming, not just technical details for using software [5]. The ability to use CT tools to carry out scientific inquiry is quickly becoming required in the modern scientific landscape. Despite this fact, high school math and science curricula have been slow to react to this trend[6].

Therefore the development of new teaching strategies is essential for all-round developments of students. Constructivist teaching is based on constructivist learning theory

ICCSET 2018, October 25-26, Kudus, Indonesia

Copyright (C) 2018 EAI

DOI 10.4108/eai.24-10-2018.2280539 
which has emerged as a prominent approach to teaching during this past decade [7]. Robotics can be used as a tool that offers opportunities for students to engage and develop computational thinking skills[8]. Furthermore, a guided instruction approach using robots facilitates teamwork, develops conceptual understanding, enhances critical thinking, and promotes higher-order learning in the domains of mathematics and science[3].

This paper aims to review the contributions of the constructivist approach through educational robotic to developing students' computational thinking. As in many similar projects[2], describes the implementation of educational robotic activity in school, focusing on the different possible impacts that the instructional approach might have on the development of students' CT skills depending on their age and gender. The paper seeks to contribute to the literature by suggesting the strategy to improve the computational thinking using the constructivist approach and educational robotics.

\section{Method}

This article adopted a literature review approach suggested by Okoli \& Schabram[2]. The literature review was conducted on the journals in advancing students' computational thinking. The following keywords were utilized: computational thinking, constructivist theory, and educational robotics. Relevant articles from several conference proceedings also examined. The following online databases and websites were employed in this searchcollection effort Google Scholar. This website was employed to search for and acquire specific references.

In addition studied from Elsevier of Computer in Human Behavior, Elsevier of Computer \& Education, Elsevier Robotic \& Autonomous System. Articles reviewed are within ten years period. Total papers studied were 15 from the computational thinking journal, 11 from the constructivist journal, 9 from Educational Robotic journal and 20 from the other journal. The number of articles reviewed along with the relevant articles obtained in the search was depicted in Fig 1.

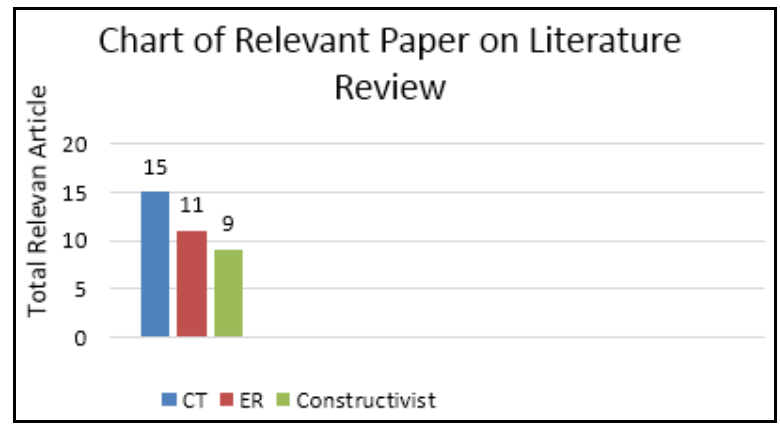

Fig. 1. Papers reviewed in the study. 


\section{Theoretical Foundation}

\subsection{Educational Robotics}

Recently, many research used the advantage of robotics that offers opportunities for students to engage in computational thinking skills[2]. The results from the research indicated that educational robotics after the intervention were improved their computational thinking, can be used to teach concepts such as designing, programming and other disciplines[2].

Table 1. The Various Educational Robotics Studies.

\begin{tabular}{|c|c|c|}
\hline Article & Context & Result \\
\hline $\begin{array}{l}\text { Atmatzidou et al. } \\
\text { [2] }\end{array}$ & $\begin{array}{l}\text { Junior High and High } \\
\text { Vocational Students }\end{array}$ & $\begin{array}{l}\text { The positive impact that students may } \\
\text { overcome their initial difficulties and } \\
\text { successfully develop their CT skill }\end{array}$ \\
\hline Bers et al. [9] & Childhood students & $\begin{array}{l}\text { A positive result that using robotics } \\
\text { were relevant CT concepts relevant to } \\
\text { sequencing and choosing the correct } \\
\text { instructions }\end{array}$ \\
\hline Chen et al. [8] & Elementary School Student & $\begin{array}{l}\text { The result indicated that the using } \\
\text { robotics programming has the potential } \\
\text { to reveal the students learning } \\
\text { challenges and growth in terms of CT }\end{array}$ \\
\hline $\begin{array}{l}\text { Cruz-Martin } \\
\text { al.[1] }\end{array}$ & Undergraduate Students & $\begin{array}{l}\text { The result indicated asses the higher } \\
\text { motivational using a complete robot } \\
\text { and the real fulfillment of the other } \\
\text { requirement in several academic years. }\end{array}$ \\
\hline $\begin{array}{l}\text { Hutamarin et al. } \\
{[10]}\end{array}$ & High School Students & $\begin{array}{l}\text { Positif impact that the using robotics in } \\
\text { a workshop, helping students to } \\
\text { develop their CT. }\end{array}$ \\
\hline
\end{tabular}

Based on table 1, the results showed that positive impact on the development of students' computational thinking skills by using the robotics. Another issue is to understand how the student improves and how to teach those computational thinking skills progressively[2].

\subsection{Computational Thinking}

Computational thinking is a concept, practices, and perspectives[9]. Computational thinking concept such as abstraction, automation, analysis, decomposition, modularisation and iterative design[2]. There are multiple definitions of CT and several suggestions about which skills and abilities are relevant to CT and how to integrate CT in the curricula of all grades[2]. Wing [10] asserts that CT has the potential to advance the students' problem-solving skills through processes such as abstraction, generalization, decomposition, algorithm design and separation of concerns. To encompass more fields, CT concepts are generalized as the usage of one of the computer science principles listed in Table 2 in solving a problem. 
Table 2. Computational Thinking Concept and Related Computer Science.

\begin{tabular}{|c|c|}
\hline Steps & Description \\
\hline Algorithmic thinking & $\begin{array}{l}\text { The steps to complete a task. Operators and expressions are also } \\
\text { included. }\end{array}$ \\
\hline Abstraction & $\begin{array}{l}\text { The generalized representation of a complex problem, ignoring } \\
\text { extraneous information }\end{array}$ \\
\hline Problem decomposition & Managing the parts that can be solved independently of each other \\
\hline Data Collection & The collection, representation, and analysis of data \\
\hline Parallelization & Simultaneous processing of a task \\
\hline Control Flow & Direct an algorithm's steps when to complete \\
\hline Incremental & $\begin{array}{l}\text { Building small parts of the program at each step instead of the whole } \\
\text { program at one }\end{array}$ \\
\hline Testing and Debugging & Performing intermediate testing and fixing problems while developing \\
\hline Questioning & $\begin{array}{l}\text { Working to understand each part of the code instead of using code that is } \\
\text { not understood well }\end{array}$ \\
\hline
\end{tabular}

Thus, finding ways the computational thinking in many research, such as proposed framework of computational thinking for the education where the robotics has the potential to reveal student learning challenges and growth in terms of computational thinking[2]. CT is an important skill that we should be teaching students of all ages[11].

\subsection{Constructivist Approach}

Constructivist approach refers to knowledge constructed by connecting new experience to existing ideas[7]. The simplest definition of constructivist evokes the idea of learning-bymaking and this is what was taking place when the students worked on their project[11]. Constructivist practices and according to student needs and interests so as to encourage their participation[12].

Table 3. Computational Thinking Concept and Related The Measure of Constructivist Approach

\begin{tabular}{ll}
\hline \multicolumn{1}{c}{ Computational Thinking [2][13] } & \multicolumn{1}{c}{ Constructivist Approach [14] } \\
\hline $\begin{array}{l}\text { Abstraction is the process of creating something simple from } \\
\text { something complicated, by leaving out the irrelevant details, } \\
\text { finding the relevant patterns, and separating ideas from tangible } \\
\text { details. Wing argues that the essence of CT is abstraction [13] }\end{array}$ & $\begin{array}{l}\text { Begin with the whole is the step of } \\
\text { expanding to parts and pursuit of } \\
\text { student questions or interests } \\
\text { about the topic }\end{array}$ \\
$\begin{array}{l}\text { Generalization is transferring a problem-solving process to a } \\
\text { wide variety of problems }\end{array}$ & $\begin{array}{l}\text { Primary Sources is manipulating } \\
\text { materials to solve the problem }\end{array}$ \\
$\begin{array}{l}\text { The Algorithm is a practice of writing step-by-step specific and } \\
\text { explicit instructions for carrying out a process. }\end{array}$ & $\begin{array}{l}\text { Learning is interaction is building } \\
\text { on what students already know } \\
\text { and in this step, the instructor } \\
\text { interacts to negotiates with } \\
\text { students }\end{array}$ \\
$\begin{array}{l}\text { Modularity is the development of autonomous processes that } \\
\text { zncapsulate a set of often used commands performing a specific } \\
\text { unction and might be used in the same or different problems } \\
\text { Decomposition is the process of breaking down problems into }\end{array}$ & \begin{tabular}{l} 
Knowledge is a step that students \\
\hline
\end{tabular}
\end{tabular}


smaller parts that may be more easily solved. Break down a problem into smaller/simpler parts that are easier to manage.

change with experiences and give

This study seeks on constructivist approach as a means for improving students' computational thinking, we concisely review next CT theoretical framework and studies on the Constructivist-ER-CT relationship. Papert suggests that learning is most effective when students are experiencing and discovering things for themselves[15].

Table 4. The various constructivist studies.

\begin{tabular}{ll}
\hline \multicolumn{1}{c}{ Article } & \multicolumn{1}{c}{ Result } \\
\hline Kim [16] & $\begin{array}{l}\text { Constructivist teaching has some effect on motivation, self- } \\
\text { development, and self-monitoring } \\
\text { The result found that the constructivist approach recommend to } \\
\text { development of students' higher achievement in science }\end{array}$ \\
Adak [7] & $\begin{array}{l}\text { Constructivist approach scores higher than the traditional } \\
\text { method on language subjects } \\
\text { Qarareh [17] }\end{array}$ \\
The result found that constructivist had a statistically significant \\
effect on communicative competency and attitudes towards \\
computer science \\
The constructivist approach had higher scores than traditional \\
teaching in social science
\end{tabular}

The table 4 showed that literature from many researchers finding that constructivist has some effect on students' achievement, motivation, self-development, self-monitoring, communicative competence, and attitude.

\section{Discussion}

\subsection{The contribution of the constructivist approach}

The constructivist approach is an interpretive, building process by active learners interacting with their surround[20]. Based on table 4 and the other research found that constructivist has some effect on students' achievement, motivation, self-development, self-monitoring, communicative competency and attitude[21]. Improving computational thinking can be using the multidisciplinary approach [22] included the constructivist approach and educational robotic. The teacher can be using the constructivist approach to helps students developing their idea from the experience[7]. Relevant to this paper reviews how to constructivist approach with educational robotic for improving students' critical thinking.

\subsection{The contribution of the educational robotic}

The educational robotic applied in the current study [2], [8], [10] found that the positive impact to develop students' CT skills. Educational Robotics has become an important skill to express ideas, inspiring student's originality while helping develop logical thinking. Many research attempts to use robotics technologies in education is increasingly common and has the potential to impact students' learning[23]. Based on table 2 and reviews the literature about 
educational robotic showed that the using of robotics gives a positive impact on the development of students' computational thinking skills.

\subsection{Combination of the educational robotic and constructivist approach to computational thinking}

Course development was guided by the main principles of the constructivist approach and computational thinking[11]. The alternative combine of the constructivist approach and educational robotics to improve the computational thinking, shown in table 4. Robotic can be used as a media or tool to help student learning experience with the tangible object include robotics[24]. The guide five principal to develop computational thinking in Hambursh et al [22] lay the groundwork for computational thinking such as present examples in a language familiar to the students, teach in a problem-driven way, the programming language should right away allow a focus on computational principles, and make effective use of visualization.

\section{Conclusion}

The literature reviewed indicated that constructivist approach with educational robotic will be very helpful to improve the computational thinking. The concept of the constructivist approach in accordance with the concept of computational thinking. The students can be gained experience on their own projects to build knowledge and computational thinking through the constructivist approach. The use of the combining robotics with the constructivist approach to learning can be given a positive influence to develop of student computational thinking.

\section{References}

[1] A. Cruz-Martín, J. A. Fernández-Madrigal, C. Galindo, J. González-Jiménez, C. StockmansDaou, and J. L. Blanco-Claraco, "A LEGO Mindstorms NXT approach for teaching at Data Acquisition, Control Systems Engineering and Real-Time Systems undergraduate courses," Comput. Educ., vol. 59, no. 3, pp. 974-988, 2012.

[2] S. Atmatzidou and S. Demetriadis, "Advancing students' computational thinking skills through educational robotics: A study on age and gender relevant differences," Rob. Auton. Syst., vol. 75, pp. 661-670, 2016.

[3] J. Lockwood and A. Mooney, "Computational Thinking in Education: Where does it Fit? A systematic literary review," 2017.

[4] J. M. Wing, "Computational Thinking, Commun," ACM 49, pp. 33-35, 2006.

[5] A. Yadav, "Computational Thinking and 21st Century Problem Solving," 2011.

[6] D. Weintrop et al., "Interactive Assessment Tools for Computational Thinking in High School STEM Classrooms," in Lecture Notes of the Institute for Computer Sciences, Social-Informatics and Telecommunications Engineering, LNICST, 2014, vol. 136 LNICST, pp. 22-25.

[7] A. Samaresh, "Effectiveness of constructivist approach on academic achievement in science at secondary level," Educ. Res. Rev., vol. 12, no. 22, pp. 1074-1079, 2017.

[8] G. Chen, J. Shen, L. Barth-Cohen, S. Jiang, X. Huang, and M. Eltoukhy, “Assessing elementary students' computational thinking in everyday reasoning and robotics programming," Comput. Educ., vol. 109, pp. 162-175, 2017.

[9] M. U. Bers, L. Flannery, E. R. Kazakoff, and A. Sullivan, "Computational thinking and tinkering: 
Exploration of an early childhood robotics curriculum," Comput. Educ., vol. 72, pp. 145-157, 2014.

[10] S. Hutamarn, S. Chookaew, C. Wongwatkit, S. Howimanporn, T. Tonggeod, and S. Panjan, "A STEM Robotics Workshop to Promote Computational Thinking Process of Pre- Engineering Students in Thailand: STEMRobot," in The 25th International Conference on Computers in Education, 2017.

[11] I. H. S. Papert, "Situating Construtivism." 1991.

[12] S. Bhutto and I. U. Chhapra, "Educational Research on \&quot; Constructivism \&quot; -An Exploratory View," Int. J. Sci. Res. Publ., vol. 3, no. 1, pp. 2250-3153, 2013.

[13] J. M. Wing, "Computational thinking and thinking about computing," Philos. Trans. R. Soc. A Math. Phys. Eng. Sci., vol. 366, no. 1881, pp. 3717-3725, 2008.

[14] T. E. Online, "Constructivism as a Paradigm for Teaching and Learning," WNET Educ., 2004.

[15] S. Papert, Mindstorms: Children, Computers, and Powerful Ideas, Basic Books. New York, 1980.

[16] J. Kim, “Academic Achievement, Self-concept, and learning strategies," Asia Pacific Educ. Rev. Copyr. by Educ. Res. Inst., vol. 6, pp. 7-18, 2005.

[17] A. O. Qarareh, "The Effect of Using the Constructivist Learning Model in Teaching Science on the Achievement and Scientific Thinking of 8th Grade Students," Int. Educ. Stud., vol. 9, no. 7, p. 178, 2016.

[18] T. J. A Enok, "Influence of constructivist approach in enhancing attitudes towards computer science at higher secondary level," Int.J.Humanities Soc. Sci, vol. 2, 2011.

[19] S. Jong, "The effect of a constructivist teaching approach on student," Eurasian J. Phys. chem. Educ, vol. 1, pp. 45--50, 2005.

[20] P. Fosnot, "Constructivism: A Physical Theory of Learning. New York \& London: Teacher College Press." 2005.

[21] C. Kim, D. Kim, J. Yuan, R. B. Hill, P. Doshi, and C. N. Thai, "Robotics to promote elementary education pre-service teachers' STEM engagement, learning, and teaching," Comput. Educ., vol. 91, pp. 14-31, 2015.

[22] S. Hambrusch, C. Hoffmann, J. T. Korb, M. Haugan, and A. L. Hosking, "A multidisciplinary approach towards computational thinking for science majors," ACM SIGCSE Bull., vol. 41, no. 1, p. 183, 2009.

[23] S. Kucuk and B. Sisman, "Behavioral patterns of elementary students and teachers in one-to-one robotics instruction," Comput. Educ., vol. 111, pp. 31-43, 2017.

[24] F. D. T, “Task Based Assessment of students' computational thinking skills developed through visual programming or tangible coding environment," in International Conference on Cognition and Exploratory Learning in Digital Age (CELDA 2016), 2016. 